\title{
Online Learning Quality of Engineering Faculty Universitas Negeri Surabaya Towards Legal Entity State University
}

\author{
Edy Sulistiyo1, Yuli Sutoto Nugroho ${ }^{2 *}$, Lilik Anifah ${ }^{3}$, Unit Three Kartini ${ }^{4}$, Maulana Rizki Aditama ${ }^{5}$, \\ Rifqi Firmansyah ${ }^{6}$, Sari Cahyaningtias ${ }^{7}$ \\ 1,2,3,4Universitas Negeri Surabaya, Surabaya, Indonesia \\ 5 University of Machester, Machester, United Kingdom \\ ${ }^{6}$ King Abdulaziz University, Jeddah, Saudi Arabia \\ ${ }^{7}$ Arizona State University, Tempe, United States
}

\begin{tabular}{|c|c|}
\hline 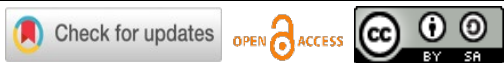 & DOI: https://doi.org/10.46245/ijorer.v3i1.182 \\
\hline Sections Info & ABSTRACT \\
\hline & \multirow{11}{*}{$\begin{array}{l}\text { Analysis of the quality of the learning process is very important in teaching } \\
\text { and learning activities in ensuring and maintaining the quality of learning } \\
\text { well. In the teaching and learning process, the quality assurance instrument } \\
\text { or learning quality is an instrument or tool that aims to improve quality in } \\
\text { the education sector through observations and assessments produced by } \\
\text { research on students. The objective of this research is to test the quality of } \\
\text { the online learning process during the Covid-19 pandemic at the Faculty of } \\
\text { Engineering (FT) of the State University of Surabaya (Unesa) towards a Legal } \\
\text { Entity Higher Education (PTN-BH). The method used in this research is } \\
\text { descriptive qualitative which aims to find out social phenomena from the } \\
\text { point of view of students and lecturers. The result of this study is that from } \\
\text { the ten statements given to respondents, all shown positive results. it can be } \\
\text { concluded that Faculty of Engineering students and lecturers support Unesa } \\
\text { to become a Legal Entity State University. }\end{array}$} \\
\hline Submitted: December 10, 2021 & \\
\hline Final Revised: January 4, 2022 & \\
\hline Accepted: January 11, 2022 & \\
\hline 31,2022 & \\
\hline Keywords: & \\
\hline Covid-19 & \\
\hline Online learning & \\
\hline PTN-BH & \\
\hline Quality of Learning & \\
\hline 回祖回 & \\
\hline
\end{tabular}

\section{INTRODUCTION}

The pandemic is caused by the Covid-19 virus, it has had a huge impact in all sectors, one of which is the education sector. With the Covid-19 pandemic, learning and teaching activities that were previously carried out face-to-face in the classroom have turned into virtual or online classes. This has an impact not only on the teaching ability of the teaching staff, but also on the mastery of technology that must be possessed by the teaching staff. The COVID-19 pandemic has compelled all educational institutes to use online learning, regardless of how ready they for this transformation (Puriwat \& Tripopsakul, 2021). In an effort to realize the State University of Surabaya (Unesa) to become a Legal Entity Higher Education (PTN-BH), lecturers in the Faculty of Engineering (FT) are required to ensure the quality of the teaching and learning process and to constantly evaluate the quality of their education. In realizing quality assurance or the quality of the learning process, lecturers in the Faculty of Engineering Unesa must have expertise and skills in qualified teaching and expertise and skills in the field of technology and IT. Digital literacy is needed by everyone to compete in the world of work (Nugroho \& Paleologoudias, 2020).

As part of the process of developing teaching and learning activities, education in the campus environment must still have good quality even though the learning process is carried out virtually remotely due to the Covid-19 pandemic. Given these conditions, it is necessary to conduct an assessment related to the quality of the teaching and learning process to ensure good quality. Online/online learning is expected to run as well as 
possible such as offline/face-to-face teaching and learning activities, and it is even hoped that it will be better, by utilizing the existing learning media to the fullest. In this case, it is necessary to have quality standards that are always maintained so that lecturers and students in the Unesa Faculty of Engineering continue to establish a teaching and learning process that is in accordance with learning objectives. Educational quality is operationalized as students' test results, indicating a narrow perspective on educational quality (Honingh et al., 2020).

The government demands that all universities in Indonesia carry out learning activities following current technological developments. Through the Ministry of Education and Culture, providing facilities for Univercity who want to hold PTN-BH status, of course, must be balanced with increasing expertise and skills in the field of technology and IT for both lecturers and students within the Faculty of Engineering Unesa. Lecturers are currently facing millennial generation and generation $\mathrm{Z}$ students where students of this generation are familiar with things related to technology so that this requires lecturers to be able to improve scientific competence and develop learning methods so that they are always up to date in answering challenges in education. Unesa has provided online lecture program facilities by providing the Surabaya State University Learning Management System (LMS) learning media, namely vi-learning on SSO. However, the use of LMS vi-learning media is currently not fully implemented among lecturers and students within the Faculty of Engineering, Unesa. This is closely related to the challenges in operating the LMS which can be said to be not user friendly, especially for the learning process for practicum courses. With this, it becomes a challenge for lecturers in the Faculty of Engineering, Unesa. The quality of learning with internet-based distance learning during the covid-19 pandemic at the Electrical Engineering Department can be said to be good from the student's views (Nugroho et al., 2021).

In the current Covid-19 pandemic, lecturers are forced to carry out online learning activities because it is not possible to carry out offline/face-to-face learning in the classroom. Moreover, Unesa is currently trying to become a PTN-BH. This is what underlies the importance of assessing the quality of learning activities in FT Unesa, how to assess the assessment of lecturers and students on online learning that has been running. In online learning, it is necessary to adapt to the mastery of technology that continues to develop. Of course, there are many obstacles in online learning activities. Apart from the rapid development of online higher education, educators and students face certain obstacles that affect the quality of distance learning in general (Markova et al., 2017). Learning outcomes depend on self-e-cacy, collaborative learning, team cohesion, technology compatibility, learning engagement, self-regulation, interests, etc. (Panigrahi et al., 2018). Internal quality assurance policies and practices are implemented by academic institutions themselves to monitor the quality of their education (Elzagheid, 2019). In an effort to improve the quality of learning there are various important components that play a role in it. Of course, learning must be active, creative, and fun/contextual learning. Apart from internal components, it is also important to pay attention to external components such as school-based management and community participation.

Online learning is an online-based learning process using the help of the internet. Online learning methods allow learning activities between lecturers and students not directly or anytime and anywhere. In online learning requires a variety of assistive devices such as laptops, PCs, tabs, and smartphones. The device used must be accessible to the internet network. The simplicity of the system is usually more attractive to students 
because it is considered more efficient. Lecturers as educators must always maintain the quality of learning like casual learning or even better so that students can absorb the knowledge given well.

In distance learning, there are various learning media, such as e-books and e-modules. Not all disciplines can apply e-learning, such as pure scientific fields. Along with the advancement of science and technology, learning resources have also been transformed into electronic. This allows students to find their own learning resources with the help of the internet. Assessment or assessment for students about the ability to complete online lectures is very important for student satisfaction using online learning (Shen et al., 2013). Online learning needs to be done because it is able to help students achieve complete learning independently. The busyness of the lecturers, which sometimes makes them unable to attend offline in class, is one of the reasons online learning is considered more effective. In addition to online learning, there are several terms in learning such as elearning and distance learning environment. Preparing young people for the challenges of the future is an important duty of higher education (Király \& Géring, 2019).

Legal Entity State Universities (PTN-BH) are state universities established by the Indonesian government and have the status of an autonomous public legal entity university in academic and non-academic midwives. The information system contained in Legal Entity State Universities (PTN-BH) is considered capable of regulating academic and non-academic where there is organizational management, finance, student affairs, staffing, and infrastructure. With a policy of full autonomy at state universities with legal entities, a state university can independently manage all the interests of its own household in accordance with the goals of the campus and it is hoped that the university can develop and innovate more quickly. Based on the formulation of the research problem, the main objectives of the research are regarding student aspirations, including:

1. Get an assessment from FT students regarding the learning that has been going on at Unesa

2. Get aspirations from FT students for future learning improvements

\section{RESEARCH METHOD}

\section{Type, Time and Place of Research}

The approach used in this research is descriptive qualitative and quantitative which aims to find out social phenomena from the student's point of view. This qualitative research is descriptive-analytic by using the natural environment as a source. The data was obtained from a questionnaire distributed to students with the help of a questionnaire platform from Google. The results of the analysis are in the form of an explanation of the situation under study in the form of a narrative which aims to narrate the conditions and analyze the assessments of the lecturers and students of the Faculty of Engineering (FT) State University of Surabaya (Unesa). The time required to carry out this research is 6 (six) months. The place of this research is the Faculty of Engineering, State University of Surabaya.

\section{Research Design}

The flow of research activities is shown in the flow chart as follows in Figure 1. 


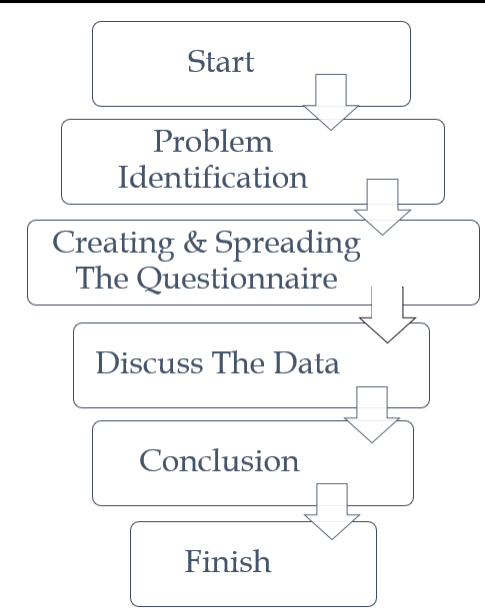

Figure 1. Research flowchart.

1. Situation and problem analysis

The quality of learning in a higher education institution needs to be studied and evaluated in the learning process so that it can channel and disseminate knowledge properly. With the Covid-19 pandemic, it has had a significant impact on the sustainability of the teaching and learning process, especially UNESA is preparing to go to PTN-BH so that everything related to teaching and learning activities must be monitored for good quality starting from offline and online learning.

2. Creation, validation, dissemination, and recapitulation of questionnaires

Questionnaires before being distributed need to be validated for their substance in order to obtain appropriate and accountable data. Furthermore, the questionnaire will be distributed to lecturers and students in the FT Unesa environment. This aims to determine their assessment of the learning that is currently running.

3. Research data analysis

The data that has been obtained is then analyzed descriptively qualitatively based on the results of processing the questionnaire. The analysis will lead to the quality of learning in FT Unesa which is presented in a narrative manner.

\section{Data Collection Instruments and Techniques}

This research uses an instrument developed by Uwes Anis Chaeruman. Data was collected by distributing questionnaires to lecturers and students of the Unesa Faculty of Engineering. The instrument used in this research is a questionnaire which will be distributed with the help of a google form. The hope is that there will be as many respondents as possible, so that the data obtained will be stronger.

\section{Data analysis technique}

In conducting data analysis, the techniques used are data reduction, data presentation and conclusion drawing. The data that has been collected is then downloaded and presented in the form of tables and graphs. The data that has been obtained is then continued by doing data reduction to be analyzed according to the needs of researchers in order to solve problems. The next stage is displaying the data so that the data is organized and arranged in a relationship pattern, so the data can be understood easily. Presentation of data can be done in various forms including: tables, percentages, graphs, diagrams, charts and narratives. The analysis used is descriptive-analytic with the aim of 
Online Learning Quality of Engineering Faculty Universitas Negeri Surabaya Towards Legal Entity State University

knowing the assessment of lecturers and students on learning at the Faculty of Engineering.

\section{RESULTS AND DISCUSSION}

The total respondents in this study were 130 people from the Faculty of Engineering, Unesa with a composition of $86.2 \%$ students and $13.6 \%$ lecturers, see Figure 2 . This number is considered to be representative of the research respondents, considering the number of students is far more than the number of lecturers with an average ratio of 1:15.

A 1-4 Likert scale is used in the instrument, by the following conditions:

$$
\begin{aligned}
& 4=\text { Very Good } \\
& 3=\text { Good } \\
& 2=\text { Less } \\
& 1=\text { Very Less }
\end{aligned}
$$

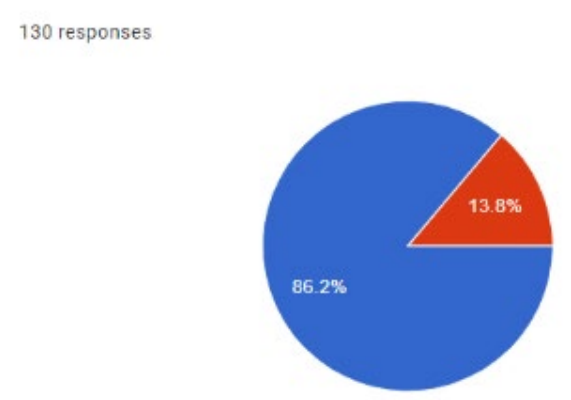

Figure 2. Respondents.

Training Design

The first statement given to respondents was about whether the learning design is cohesive (integrated) and aligned with the objectives, assessments, and learning activities. The majority of respondents consisting of students and lecturers gave 3 points which means they agree with the statement, see Figure 3.

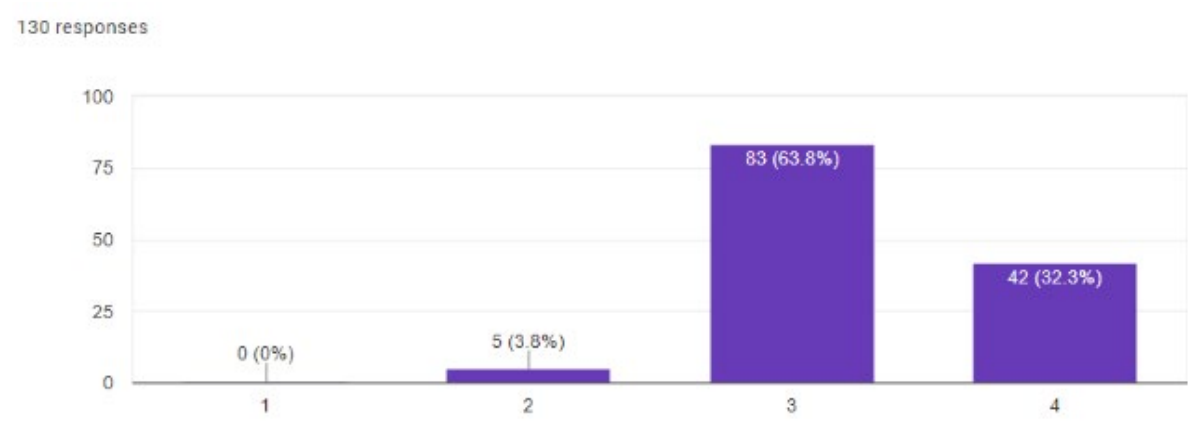

Figure 3. Design.

Still regarding the design of the training courses, respondents were asked about the learning load that was designed logically and evenly distributed. The results showed that the research subjects agreed that the lesson was well designed with almost half of all respondents answering. the relationship between competence and curriculum and core educational quality and loyalty is mediated by transformative quality and satisfaction (Nguyen et al., 2021). Furthermore, the respondents were asked to assess whether in learning they apply student-centered learning principles and encourage interesting and engaging interactions. The majority of them answered agree with this statement, even 
$40.8 \%$ of the respondents strongly agree that learning has prioritized interaction with students. Adequate instructional methods, support, course structure, and design can facilitate student performance and satisfaction (Kauffman, 2015). Overall, from the three statements related to the design of the training courses, students and lecturers agreed that the learning in the Faculty of Engineering Unesa had a good training plan. Lecturers are expected to be able to provide material that is packaged in a fun way (Nugroho et al., 2021).

\section{Accessibility}

130 responses

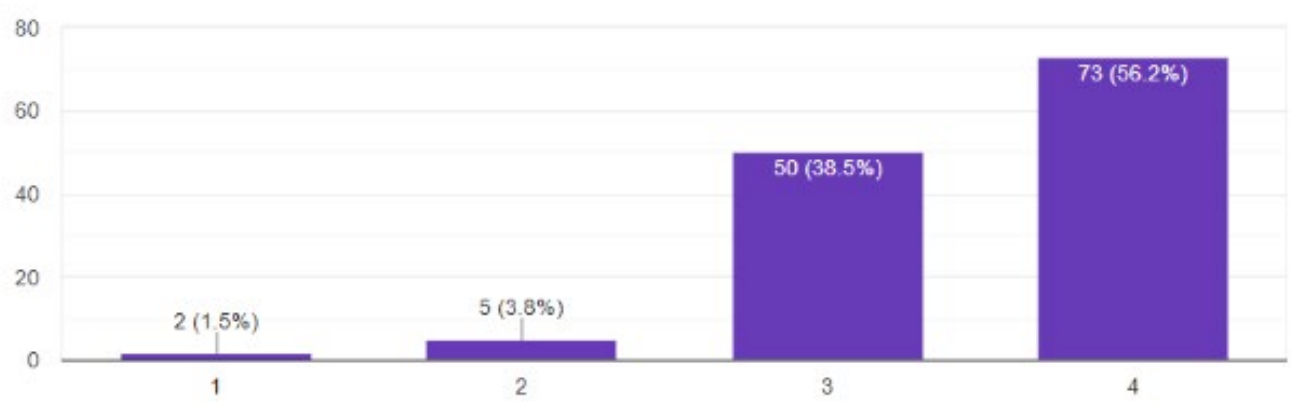

Figure 4. Ease of access anywhere.

Both students and lecturers strongly agree that online learning that has been implemented has the convenience of being accessed anytime and anywhere by anyone. A total of $56.2 \%$ of respondents strongly agree and $38.5 \%$ agree with the statement, it can be seen in Figure 4. At the point of accessibility, the second question asked is the ease of being accessed anytime and anywhere by anyone. The results of the questionnaire show that $60.8 \%$ of respondents strongly agree that learning is easily accessible. Regarding the ease with which it can be accessed by any device (desktop, laptop, tablet, cellphone, etc.), the results are similar to the previous statement that more than half of the respondents strongly agree that learning is easily accessible massively. instructional activities will become more hybrid provided the challenges experienced during this pandemic are well explored and transformed to opportunities (Adedoyin \& Soykan, 2020). All statements regarding the accessibility of online learning get very positive results, which are dominated by answers that strongly agree that online learning established at the Unesa Faculty of Engineering is very accessible. Network security is a substantial necessity with the enormous use of the Internet (da Costa et al., 2019).

\section{Learning Outcomes}

Regarding learning outcomes, there are statements about learning outcomes according to critical thinking and solving relevant complex problems. In Figure 5, the results of this statement indicate that the majority of respondents agree with this statement as much as $59.2 \%$. In terms of learning achievement points, other statements are regarding (1) Learning achievement is stated clearly and can be measured, and (2) Learning achievement demands the achievement of excellent work from students, from the two statements the results are similar to the previous statement, where the majority of lecturers and students agree. Adversary evaluation implicates both training and testing (Li et al., 2017). 


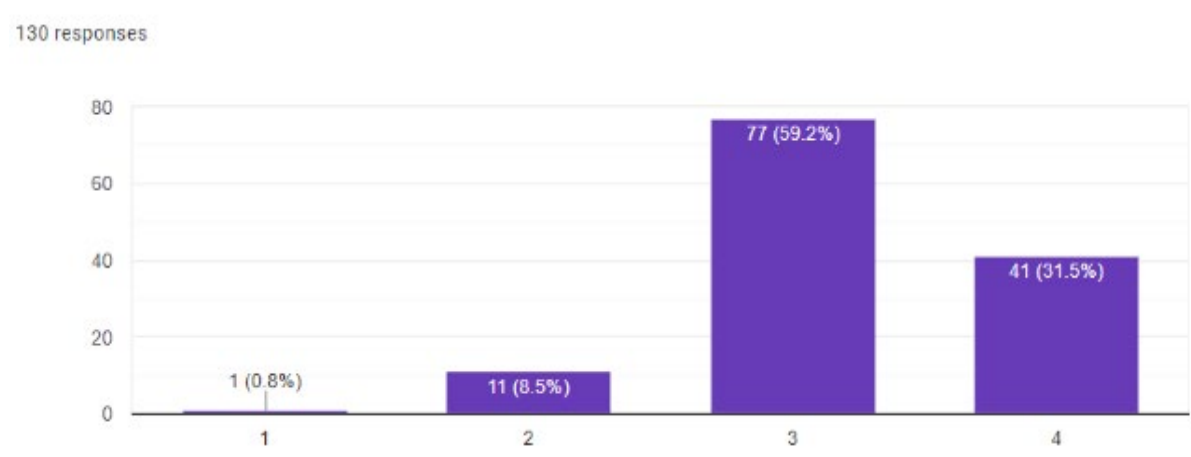

Figure 5. Learning outcomes.

\section{Learning Content}

The focus of further research is on learning content, where there are 3 main questions, namely: (1) Learning content includes all predetermined learning outcomes, (2) Learning content is in line with learning outcomes, and (3) Learning content is packaged and presented in a variety of ways. a variety of relevant digital media. From the three questions, it was concluded that the respondents agreed that the learning content in online learning was good, Figure 6 shows the deatil. Student literacy and character movements are some forms of learning innovation that need to be applied to similar competencies (Nurtanto et al., 2019). How the teachers who are adapt themselves, their teaching mastery, and exercises for carrying out ICT in education is a crucial issue (Dubey, 2016).

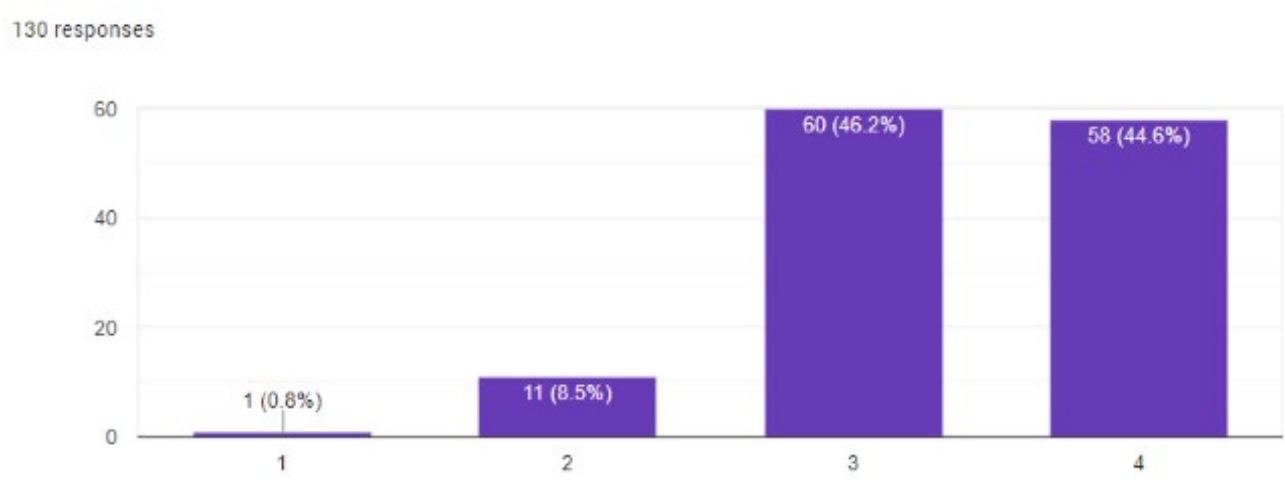

Figure 6. Learning content.

\section{Task Activities}

Regarding task activities, respondents were asked to assess 3 things, namely the tasks given in accordance with predetermined learning outcomes, the tasks given were logical, structured and possible to be achieved properly, and the tasks given were challenging and demanded "excellent" work results in accordance with expected learning outcomes. From the three statements given, students and lecturers agreed that everything was good, with a percentage of around $60 \%$, see Figure 7 . Evidence from the qualitative study supports students following a development framework for video creation (Campbell \& Cox, 2018). First term experience of student's first year of university is not promoting their intellectual development in the absence of a metacognitive prompt (Haave et al., 2018). 


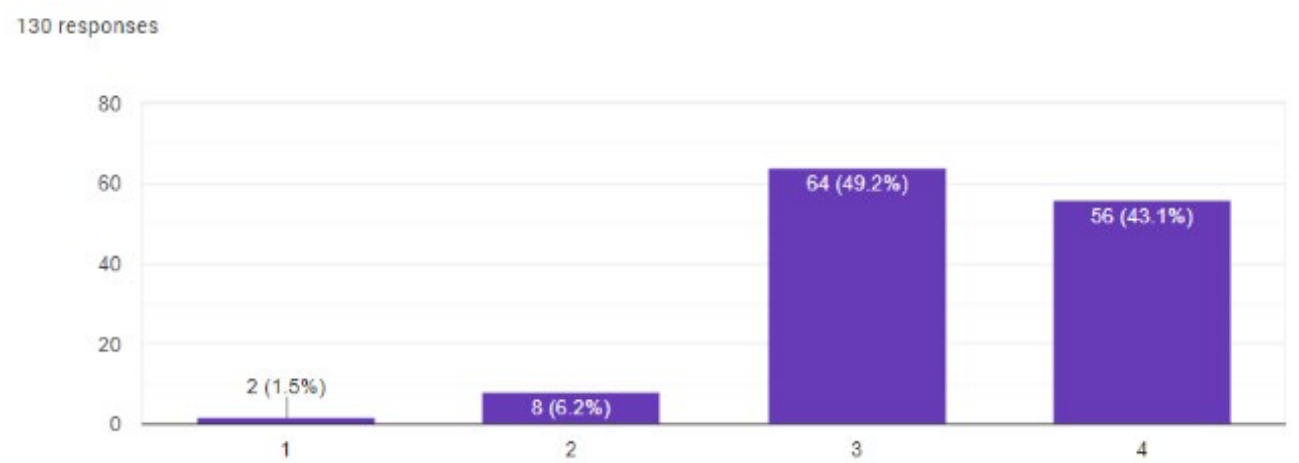

Figure 7. Task activities.

\section{Discussion Forum Activities}

The activity of the discussion forum was also asked in this study by raising several main questions, including: (1) The discussion was given argumentative and contextual case/problem-based, (2) The explanation of the discussion rules was presented clearly and encouraged challenging interactions, and (3) The discussion provided allows critical thinking and "problem solving" to occur. The results show that the majority of respondents agree that the discussion forum activity on online learning is good, see Figure 8 for the detail. The recommendations were to train faculty on using online modalities and developing lesson plan with reduced cognitive load and increased interactivities (Mukhtar et al., 2020).

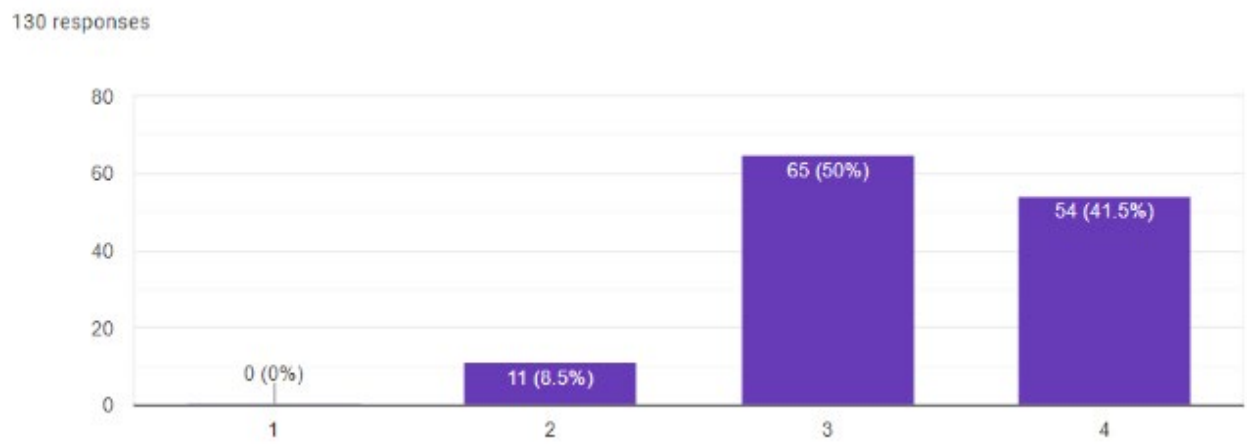

Figure 8. Discussion forum activities.

\section{Evaluation of Learning Outcomes}

Next is the point regarding the evaluation of learning outcomes, where the results are similar to other instruments, namely more than half of the total respondents agree that the evaluation of learning outcomes given requires high-level thinking skills. In addition, they also agree with the possibility of self and formative evaluation and encourage reflective and action learning, loot at Figure 9. And also agree with that learning uses various types and forms of evaluation of learning outcomes that are in line with learning outcomes. animation media that can be used in Evaluation learning outcomes which are then expected to improve student learning outcomes (Sugiharti et al., 2020). High expectations, and high achievement is the most important predictor of future educational behavior among students (Khattab, 2015). 
130 responses

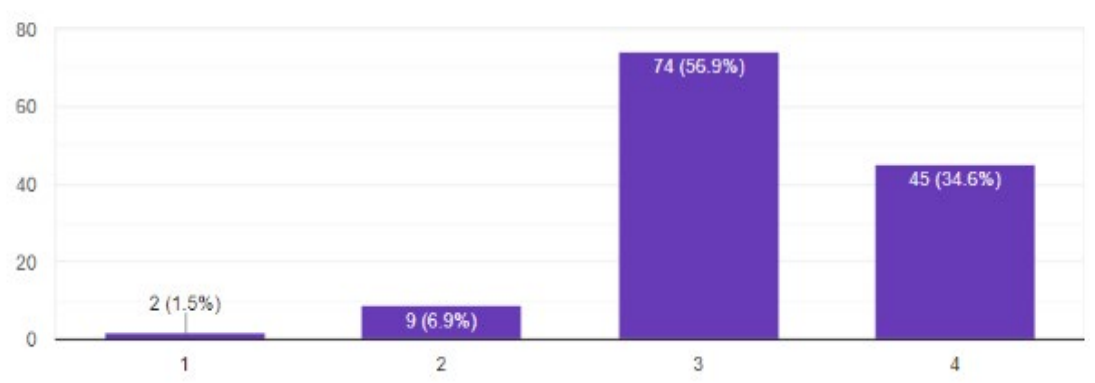

Figure 9. Evaluation of learning outcomes.

\section{Communication}

Another important point to ask is about communication. Among the three main statements, namely (1) the intensity of communication between instructors and learning participants, (2) the level of responsiveness in facilitating discussion responses in forums, and (3) the level of responsiveness in providing feedback on task activities, Figure 10 shows that about two thirds of respondents answered agree with the statements given. In fact, many of them also strongly agree. the development of strategies targeting at strengthening communication has become a central topic in clinical and social research (Sun et al., 2020). faculty should appropriately slow down their speech to allow students to capture key knowledge points (Bao, 2020).

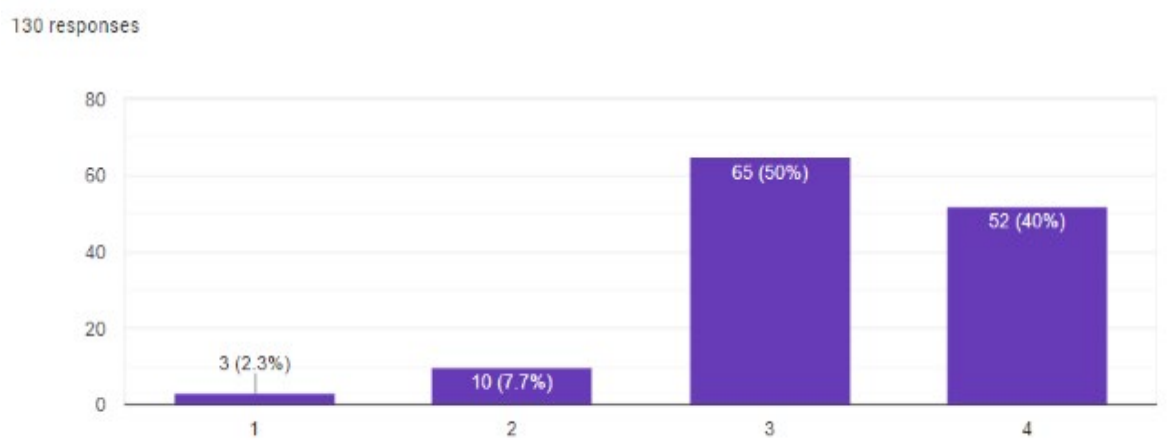

Figure 10. Communication.

\section{Building Community}

No less important than the previous instrument, there are three statements about the community. From Figure 11, it was found that the majority of students and lecturers strongly agreed that learning from FT Unesa was very good for building community. The three statements include: Lecturers build spaces for open communication; friendly and constructive; Lecturers build an open and pleasant climate of collaboration and cooperation; and Lecturers build a positive environment, build and motivate each other. The industry is currently transforming full digitalization and intelligentization of manufacturing processes (Erol et al., 2016). Machine learning communicates the issue of how to create computers that increase authority automatically through opportunity (Jordan \& Mitchell, 2015). 


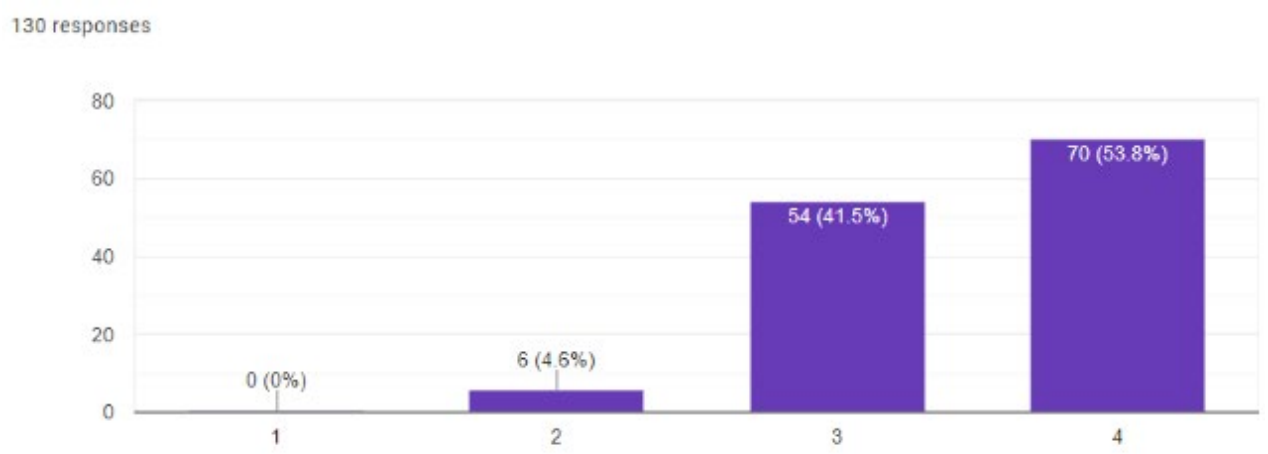

Figure 11. Building a community.

\section{Continuous Improvement}

The last group of statements that were asked of students and lecturers at FT Unesa were several things about continuous improvement, with the following details: (1) Lecturers always improve the quality of the content of the courses they teach, (2) Lecturers always evaluate the effectiveness of learning and renew it, and (3) Provide an open survey to receive feedback from students. From all these statements the majority of respondents answered agree, see Figure 12. the development of gamified actions in the face-to-face phase of flipped learning improves the motivation, interaction with teachers, and interactions of students (Sánchez et al., 2020). E-learning system allows the teacher to manage two-tier diagnostic assessments, dynamic assessment (instructional assessment), and e-learning material content (Wang, 2014).

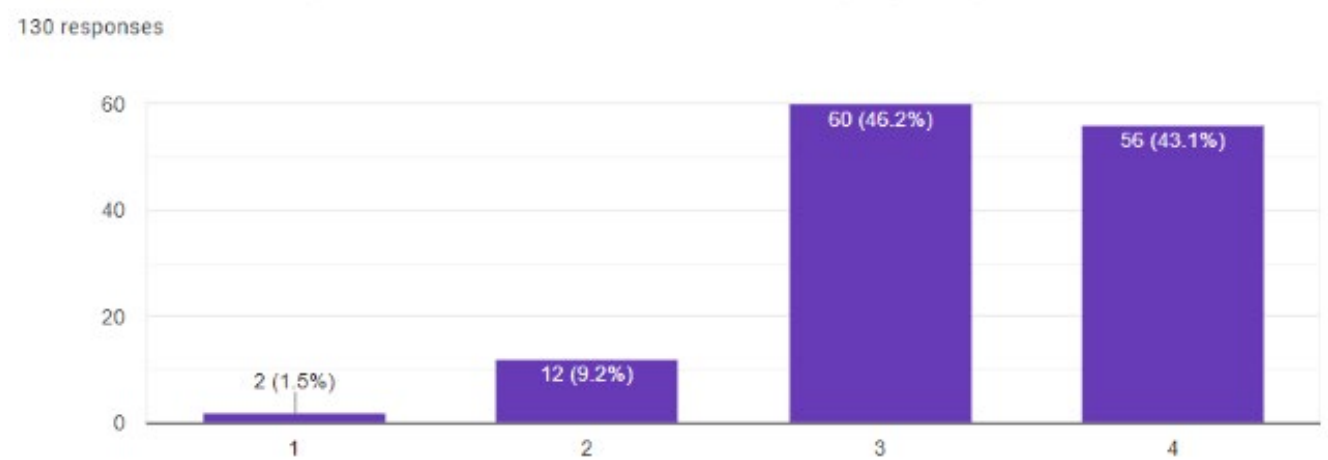

Figure 12. Continuous improvement.

\section{CONCLUSION}

The fundamental research is that there are 10 main statements given to students and lecturers around the Faculty of Engineering, State University of Surabaya. The ten questions include: Course Design, Accessibility, Learning Outcomes, Learning Content, Task Activities, Discussion Forum Activities, Evaluation of Learning Outcomes, Communication, Community Building, and Continuous Improvement. From all the statements given, very positive feedback was obtained, where on average the respondents agreed that the quality of online learning that had been running at Faculty of Engineering Unesa could be said to be good. This is certainly a good point for Unesa, which immediately changed its status from public service agency (BLU) to Legal Entity Higher Education (PTN-BH). From the results of this study, it can be concluded that lecturers and students at the Faculty of Engineering are satisfied with online learning and 
support Unesa to become a Legal Entity Higher Education (PTN-BH). The implication of this research is as a policy reference for online learning at Unesa in the next time. This research is still limited to the scope of the Faculty of Engineering, Unesa. The next research plan is to expand the research subject to university level.

\section{ACKNOWLEDGEMENTS}

The authors thank to the Faculty of Engineering, Universitas Negeri Surabaya for giving funding for this research.

\section{REFERENCES}

Adedoyin, O. B., \& Soykan, E. (2020). Covid-19 pandemic and online learning: The challenges and opportunities. Interactive Learning Environments, 2020(5), 1-13. https:/ / doi.org/10.1080/10494820.2020.1813180

Bao, W. (2020). COVID-19 and online teaching in higher education: A case study of Peking university. Human Behavior and Emerging Technologies, 2(2), 113-115. https://doi.org/10.1002/hbe2.191

Campbell, L. O., \& Cox, T. (2018). Digital video as a personalized learning assignment: a qualitative study of student authored video using the ICSDR model. Journal of the Scholarship of Teaching and Learning, 18(1), 11-24. https://doi.org/10.14434/josotl.v18i1.21027

da Costa, K. A. P., Papa, J. P., Lisboa, C. O., Munoz, R., \& de Albuquerque, V. H. C. (2019). Internet of things: A survey on machine learning-based intrusion detection approaches. Computer Networks, 151(1), 147-157. https://doi.org/10.1016/j.comnet.2019.01.023

Dubey, A. D. (2016). ICT in education. International Journal of Information and Communication Technology Education, 12(4), 37-50. https:/ / doi.org/10.4018/IJICTE.2016100104

Elzagheid, M. I. (2019). Jubail industrial college (JIC) educational quality assurance and management procedures: Chemical and process engineering technology department as an example. European Journal of Educational Research, 8(3), 659-669. https:// doi.org/10.12973/eu-jer.8.3.659

Erol, S., Jäger, A., Hold, P., Ott, K., \& Sihn, W. (2016). Tangible industry 4.0: A scenario-based approach to learning for the future of production. Procedia CIRP, 54(1), 13-18. https://doi.org/10.1016/j.procir.2016.03.162

Haave, N. C., Keus, K., \& Simpson, T. (2018). A learning philosophy assignment positively impacts student learning outcomes. Collected Essays on Learning and Teaching, 11(1), 42-64. https://doi.org/10.22329/celt.v11i0.4969

Honingh, M., Ruiter, M., \& Thiel, S. van. (2020). Are school boards and educational quality related? Results of an international literature review. Educational Review, 72(2), 157-172. https://doi.org/10.1080/00131911.2018.1487387

Jordan, M. I., \& Mitchell, T. M. (2015). Machine learning: Trends, perspectives, and prospects. Science, 349(6245), 255-260. https://doi.org/10.1126/science.aaa8415

Kauffman, H. (2015). A review of predictive factors of student success in and satisfaction with online learning. Research in Learning Technology, 25(1), 1-13. https://doi.org/10.3402/rlt.v23.26507

Khattab, N. (2015). Students' aspirations, expectations and school achievement: What really matters? British Educational Research Journal, 41(5), 731-748. https://doi.org/10.1002/berj.3171

Király, G., \& Géring, Z. (2019). Editorial: Introduction to 'futures of higher education' special issue. Futures, 111(3), 123-129. https:// doi.org/10.1016/j.futures.2019.03.004

Li, J., Monroe, W., Shi, T., Jean, S., Ritter, A., \& Jurafsky, D. (2017). Adversarial learning for neural dialogue generation. EMNLP 2017 - Conference on Empirical Methods in Natural Language Processing, 2017(1), 2157-2169. https://doi.org/10.18653/v1/d17-1230 
Online Learning Quality of Engineering Faculty Universitas Negeri Surabaya Towards Legal Entity State University

Markova, T., Glazkova, I., \& Zaborova, E. (2017). Quality issues of online distance learning. $\begin{array}{llll}\text { Procedia-Social and } \quad \text { Behavioral } & \text { 68iences, }\end{array}$ https://doi.org/10.1016/j.sbspro.2017.02.043

Mukhtar, K., Javed, K., Arooj, M., \& Sethi, A. (2020). Advantages, limitations and recommendations for online learning during covid-19 pandemic era. Pakistan Journal of Medical Sciences, 36(4), 27-31. https://doi.org/10.12669/pjms.36.COVID19-S4.2785

Nguyen, T. T., Pham, H. H., Cao, Q. T., Nguyen, X. A., \& Do, M. T. (2021). Investigating the impacts of core educational quality on the satisfaction and loyalty of parents of secondary school students: The mediating role of transformative quality. Cogent Education, 8(1), 1-20. https:/ / doi.org/10.1080/2331186X.2021.1911283

Nugroho, Y. S., \& Paleologoudias, A. K. (2020). Differences between students from senior high school and vocational school in the learning outcomes of electrical engineering students. International Conference on Vocational Education and Electrical Engineering (ICVEE), 3(1), 1-5. https://doi.org//10.1109/ICVEE50212.2020.9243189

Nugroho, Y. S., Anifah, L., Sulistiyo, E., Cahyaningtias, S., \& Rifqi Firmansyah. (2021). Analysis of learning quality with internet-based distance learning during the covid-19 pandemic. IJORER: International Journal of Recent Educational Research, 2(1), 96-110. https://doi.org/10.46245/ijorer.v2i1.81

Nugroho, Y. S., Munoto, Basuki, I., Ismayati, E., \& Paleologoudias, A. (2021). Future educational aspirations of electrical engineering students. Vocational Education and Electrical Engineering (ICVEE), 4(1), 1-6. https:/ / doi.org/10.1109/ICVEE54186.2021.9649718

Nurtanto, M., Sofyan, H., Fawaid, M., \& Rabiman, R. (2019). Problem-based learning (PBL) in industry 4.0: Improving learning quality through character-based literacy learning and life career skill (LL-LCS). Universal Journal of Educational Research, 7(11), 2487-2494. https://doi.org/10.13189/ujer.2019.071128

Panigrahi, R., Srivastava, P. R., \& Sharma, D. (2018). Online learning: Adoption, continuance, and learning outcome-a review of literature. International Journal of Information Management, 43(1), 1-14. https://doi.org/10.1016/j.ijinfomgt.2018.05.005

Puriwat, W., \& Tripopsakul, S. (2021). The impact of e-learning quality on student satisfaction and continuance usage intentions during covid-19. International Journal of Information and Education Technology, 11(8), 368-374. https://doi.org/10.18178/ijiet.2021.11.8.1536

Sánchez, S. P., Belmonte, J. L., Cabrera, A. F., \& Núñez, J. A. L. (2020). Gamification as a methodological complement to flipped learning an incident factor in learning improvement. Multimodal Technologies and Interaction, 4(2), 12-20. https://doi.org/10.3390/mti4020012

Shen, D., Cho, M. H., Tsai, C. L., \& Marra, R. (2013). Unpacking online learning experiences: Online learning self-efficacy and learning satisfaction. Internet and Higher Education, 19(1), 10-17. https://doi.org/10.1016/j.iheduc.2013.04.001

Sugiharti, G., Dalimunthe, M., \& Syuhada, F. A. (2020). Learning media animations for subject evaluation and chemistry learning outcomes. Journal of Physics: Conference Series, 1462(1), 15. https://doi.org/10.1088/1742-6596/1462/1/012021

Sun, C., Zou, J., Zhao, L., Wang, Q., Zhang, S., Ulain, Q., Song, Q., \& Li, Q. (2020). New doctorpatient communication learning software to help interns succeed in communication skills. BMC Medical Education, 20(1), 1-8. https://doi.org/10.1186/s12909-019-1917-z

Wang, T. H. (2014). Developing an assessment-centered e-Learning system for improving student learning effectiveness. Computers and Education, 73(1), 189-203. https://doi.org/10.1016/j.compedu.2013.12.002 
Online Learning Quality of Engineering Faculty Universitas Negeri Surabaya Towards Legal Entity State University

Dr. H. Edy Sulistiyo, M.Pd.

Department of Electrical Engineering, Faculty of Engineering

Universitas Negeri Surabaya

Jl. Lidah Wetan, Surabaya, East Java, 60213, Indonesia

Email: edysulistiyo@unesa.ac.id

* Yuli Sutoto Nugroho, S.Pd., M.Pd. (Corresponding Author)

Department of Electrical Engineering, Faculty of Engineering

Universitas Negeri Surabaya

Jl. Lidah Wetan, Surabaya, East Java, 60213, Indonesia

Email: yulinugroho@unesa.ac.id

\section{Dr. Lilik Anifah, S.T., M.T.}

Department of Electrical Engineering, Faculty of Engineering Universitas Negeri Surabaya

Jl. Lidah Wetan, Surabaya, East Java, 60213, Indonesia

Email: lilikanifah@unesa.ac.id

\section{Unit Three Kartini, S.T., M.T., Ph.D}

Department of Electrical Engineering, Faculty of Engineering Universitas Negeri Surabaya

Jl. Lidah Wetan, Surabaya, East Java, 60213, Indonesia

Email: unitthree@unesa.ac.id

Maulana Rizki Aditama, S.Si., M.Sc.

Department of Earth Science

University of Machester

Oxford Rd, Manchester, M13 9PL, United Kingdom

Email: maulana.aditama@postgrad.manchester.ac.uk

Rifqi Firmansyah, S.T., M.T.

Department of Electrical and Computer Engineering

King Abdulaziz University

Jeddah 21589, Saudi Arabia

Email: r.muktiadji@stu.kau.edu.sa

Sari Cahyaningtias, S.Si., M.Si.

School of Mathematical and Statistical Sciences Graduate Students

Arizona State University

Tempe, Arizona, 85281, United States

Email: scahyani@asu.edu 